FRANK PLUMPTON RAMSEY AND THE POLITICS OF MOTHERHOOD

BY SOROUSH MAROUZI *

\begin{abstract}
This paper is an attempt to historicize Frank Plumpton Ramsey's Apostle talks delivered from 1923 to 1925 within the social and political context of the time. In his talks, Ramsey discusses socialism, psychoanalysis, and feminism. Ramsey's views on these three intellectual movements were inter-connected, and they all contributed to his take on the then policy debates on the role of women in economy. Drawing on some archival materials, biographical facts, and the historiographical literature on the early inter-war politics of motherhood, I show that Ramsey held a positive view of the feminist campaign for family endowment. He demanded government financial support for motherhood in recognition of the economic significance of women's domestic works and as what could bring economic independence to them. In addition, he found such economic scheme compatible with the kind of maternalism endorsed by Freudian psychoanalysis - his favorite theory of psychology.

* Ph.D. Candidate in history and philosophy of science at the University of Toronto.

Contact: soroush.marouzi@,mail.utoronto.ca
\end{abstract}

This "preprint" is the peer-reviewed and accepted typescript of an article that is forthcoming in revised form, after minor editorial changes, in the Journal of the History of Economic Thought (ISSN: 1053-8372), issue TBA. Copyright to the journal's articles is held by the History of Economics Society (HES), whose exclusive licensee and publisher for the journal is Cambridge University Press.

(https://www.cambridge.org/core/journals/journal-of-the-history-of-economic-thought)

This preprint may be used only for private research and study and is not to be distributed further.

The preprint may be cited as follows:

Marouzi, Soroush. Frank Plumpton Ramsey and the Politics of Motherhood. Journal of the History of Economic Thought (forthcoming). Preprint at SocArXiv, osf.io/preprints/socarxiv 


\title{
Frank Plumpton Ramsey and the Politics of Motherhood
}

\author{
BY \\ Soroush Marouzi ${ }^{*}$
}

\section{INTRODUCTION}

Frank Plumpton Ramsey (1903-1930) was a member of the Cambridge Apostles, an all-male secretive debating society, the membership of which included the intellectual elite of the university. Each week an Apostle was chosen to give a talk on a subject. The subjects varied from philosophy to economics and politics. Ramsey delivered four Apostle talks between 1923 and 1925; namely, "Socialism and Equality of Income” (1923), “An Imaginary Conversation with John Stuart Mill" (1924), "Sex from the Point of View of Society" (1924), and "Civilization and Happiness" (1925). Apostle talks were mostly informal intellectual investigations, not typical scholarly works. Ramsey's talks remained faithful to the tradition: they are extremely poor in reference, they contain some scattered remarks on socialism, psychoanalysis, and feminism, however, the main arguments are not as clear as one would expect to see in academic papers.

Ramsey made significant contributions to various fields in mathematics, philosophy, and economics. As Misak (2020) shows, Ramsey's interests in intellectual movements of his time were integral to his long-lasting contributions. Building upon Misak's narrative, this paper is an attempt to historicize Ramsey's Apostle talks to reveal the complex nexus of his intellectual interests and 
to show how he developed his economic mind in tandem with thinking over the merits of socialism, feminism, and psychoanalysis. Ramsey's contribution to economics is mostly known through his two economic papers published in Economic Journal that captured his economics research agenda (Ramsey 1927 \& 1928; see Duarte 2009). Nonetheless, his engagement with economic questions were present very early on. From since he was a high school boy, he had the habit of thinking about economic questions along with mathematical and philosophical ones (see Duarte 2017 and Misak 2020). We shall see that Ramsey's Apostle talks reveal his attempt to contribute to the then policy debates on the role of women in economy.

The outbreak of World War I or the Great War as it was then known led to a substantial increase of women in the labor market. Once the war was over, women's role in the economy became a hot topic in public discussions. The male dominated organizations such as the Labor Party and Trade Unions argued that women ought to leave their wartime jobs and head back home, freeing up the jobs for the de-mobbed soldiers. Women's movement largely regarded the Labor party's effort to push them out of the workforce as a setback. However, they did not respond with one voice. On the one hand, some feminists with liberal inclination such as Millicent Fawcett argued for keeping women in the workforce and took the ideal of equal pay for equal work to be their objective. On the other hand, such ideal did not seem to be an achievable objective in the view of some other feminists such as Eleanor Rathbone. To these feminists, freeing women from the chain of domestic economic dependence was a necessary requirement on the way to achieve equality. Then, they ran the family endowment campaign, demanding for government financial support for motherhood in recognition of the economic significance of women's domestic works. 
Ramsey had been walked through the world of politics and feminism by Agnes (his mother). He soon became an avid reader of left-wing politics and got himself acquainted with various views on the economic status of women by reading important works on the subject such as Barbara Drake's Women in the Engineering Trades (1917). Thanks to Agnes, he had also firsthand experience at having occasional conversations with some of the leading figures of socialism such as Hugh Dalton who happened to be heavily involved in the public debates over the status of women in economy. In his Apostle talks, Ramsey waded into the debates over feminism (and among feminists) that were active in the early interwar period. In particular he discussed the economic and eugenic implications of the feminist views on family wage, equal pay, family endowment, and gendered division of labor. In his last talk, he put forward his judgement as follows: "not merely is feminism bad for the race but it is unfortunate for the women also" (Ramsey [1925] 1992, p. 324). It would be easy to read a comment such as this as a declaration of hostility to feminism in general. However, Ramsey's views are more complex and more nuanced. What is more, as mentioned above, the early interwar feminism in Britain itself formed a complex landscape and, surprisingly perhaps, Ramsey's views turn out to be compatible with an important strand of feminism (that ran the family endowment campaign) and in dialogue with other important intellectual currents of the day - eugenics and Freudian psychoanalysis.

Ramsey's comments on feminism have been subjected to contradictory readings. Margaret Paul, Ramsey's sister, has read her brother's remarks as "an attack on feminism” (2012, p. 219). Misak, however, argues that in Ramsey's view "feminism is progress" (2020, p. 231; emphasis original). I argue that this interpretative controversy can be resolved by placing Ramsey's remarks in the context of the debates among British feminists themselves. The main questions are: what kind of feminism was Ramsey attacking? And what kind of feminism did he take to be the 
progressive one? Ramsey, I argue, objected to liberal feminism that sought to minimize differences between men and women, but favored the other feminist camp that demanded adequate support for women and offered them financial independence. I show that Ramsey's interest in Freudian psychoanalysis and his observation of the unorthodox attitudes toward sex and love in Cambridge were constitutive to his positive view of the family endowment campaign.

\section{RAMSEY: THE SOCIALIST}

Frank Ramsey was born to an upper middle-class Cambridge family in 1903. His father, Arthur, was a mathematics Fellow and President at Magdalene College, Cambridge, and his mother, Agnes, was educated at Oxford at a time when not many women were sent to university. Agnes co-founded the Cambridge branch of the Federation of University Women and was an active member of the pre-war suffragist movement when she held a position on the organizing committee of the Cambridge Association for Women's Suffrage. She had keen interest in left-wing politics and made the Ramseys' house a welcoming place for Labor Party gatherings and suffragist discussions (Misak 2020, p. 10). Frank had close relationship with his mother (see Misak 2020, pp. 282-283) ${ }^{1}$. As Arthur said, Agnes passed on her interests in politics and taking side with the poor to Frank (see Misak 2020, pp. 19 \& 46; and, Duarte 2017).

Frank got himself engaged with politics as early as he was a high school boy. He entered Winchester, an academically top public school in 1915, only one year after the outbreak of war. At Winchester, he started to exchange letters with the Glasgow Communist Party and was called

\footnotetext{
${ }^{1}$ In this section, I refer to Frank Ramsey as "Frank" to avoid the ambiguity that "Ramsey" may imply in referring to Frank's parents.
} 
a "Bolshie." He was actively engaged in public student debates, arguing for a specific brand of socialism known as Guild socialism (Misak 2020, pp. 44-45). Guild socialism was a non-Marxist variation of socialism. It was a socialist position for it shared the socialist objective of the emancipation of labor, but it was not a Marxist one for it had no interest in state ownership or collectivism. What it wanted was the control of industry by the workers themselves through the operation of guilds in the society. Guild socialism was a short-lived movement; it initiated around 1915 and ended up with the failure of the General Strike in 1926 (Brukitt 1977, p. 8), in support of which Ramsey signed a letter (Misak 2020, p. 250).

The wartime experience and the Agnes influence loomed large in a few student essays that Frank wrote in 1920, a few months after he entered the University of Cambridge as an undergraduate student in mathematics. The essays were written with strong leftist tone, indicating a teenager's eagerness and curiosity in discussing history, politics, and economics. In one of them he put forward some positive remarks on the universal suffrage, in another discussed the economic consequences of war, and yet another one reveals his concerns about the economic condition of working-class people (ASP.1983.01: 007-02-02). Frank continued to sharpen his notion of socialism during his undergraduate years, when he was surrounded by some Cambridge intellectuals with keen interest in left-wing politics. He soon became a close friend of Maurice Dobb who started his degree at the same time as Frank. Dobb joined the British Communist Party in 1920, and his debates with Frank and other Cambridge socialist and communist students contributed to the formation of the Cambridge University Labour Club in the same year (Misak 2020, p. 79). Frank hardly ever missed a meeting of the Cambridge University Socialist Society (CUSS) in his first year at Cambridge. G. D. H. Cole, an intellectual leader of guild socialism, gave a talk at Cambridge during Frank's first year. Frank found the speech "great" and spent some 
time with Cole after his talk (Misak 2020, p. 86). Nonetheless, in a paper titled "Mr. Cole's Social Theory" (ASP.1983.01: 006-07-09), delivered to CUSS by the end of his first year at Cambridge, he criticized the ethical basis of Cole's social philosophy, revealing his changing conception of the merits of guild socialism.

Although it seems safe to say that Frank remained interested in the left-wing politics throughout his life, it is difficult to classify him as a proponent of a particular political party. In any case, once he was set to deliver his Apostle talks, he had turned his back to guild socialism and had become more interested in state-ownership and welfare policies as he was convinced of their positive consequences for both patterns of production and distribution of income (see e.g. Ramsey [1923] 1992, pp. 316-317).

\section{THE GREAT WAR AND THE ECONOMY OF FAMILY}

By the time Ramsey became interested in economics and politics, the economy was undergoing some important changes. The Great War dislocated the sex composition of British labor market and family life. Many men left for warfronts and women found unusual opportunity to work outside home. Pre-war regulations against the employment of married women in waged works softened and they were encouraged to get involved behind the scene of war (see Pugh 1992, p. 20; Pedersen 1993, pp. 89-91; and, Allen 2005, p. 113). This meant that the dominant notion of gendered division of labor within family life had to be reconsidered. The male-breadwinner norm and the separate-sphere ideology of the prewar had it that the father is responsible for the financial needs of family and the mother's role is to take care of household works and child-rearing. But now the mother had to take over the role of breadwinner besides doing her traditional domestic tasks. This was not a smooth transition. Women's improved presence in market activities could 
hardly be enough to satisfy the economic needs of family life during the war. Women were paid less than men for an equal work and the war had left its mark on everyday life expenses very quickly (see Hannam and Hunt 2002, p. 145; and, Gregory 2008, p. 195). From the beginning of the war, the arguments around the social responsibility of the state with respect to the economic status of soldiers' families gathered force and the government was asked to step in.

In August 1914, Herbert Henry Asquith, the prime minister, announced that separation allowances would be soon in effect, aiming to maintain high standard of living for soldiers' families during the war. Meanwhile, the dominant political discourse of the time was careful enough to interpret the rationale behind the allowances as the one compatible with the malebreadwinner norm. It was argued that women are eligible recipients of the allowances because they are wives of soldiers who have put themselves at the service of the state at warfronts, not because of their own rights (see Pedersen 1990, p. 997 \& 1004; and, Pedersen 1993, pp. 112-119 \& 129). In this way, British welfare policy emerged out of the presupposition that women are dependent wives. But if separation allowances were justified on the ground that the state ought to be "a surrogate husband" during the absence of men, there was no reason for the government to continue the payments once the war was over (Pedersen 1990, p. 985). The temporary nature of separation allowances was repeatedly mentioned by those who did not want the male-breadwinner norm to be threatened by the wartime experience (see Pedersen 1993, pp 92-93 \& p. 106). What they wanted after the war was a "normal" market with its traditional patriarchal patterns.

Nonetheless, the "normalization" of market confronted resistance from a group of feminists, later known as "new feminists," led by Eleanor Rathbone. These feminists wanted the allowances to be continued after the war, for they believed that they could make women free from 
the chain of domestic economic dependence. But another interpretation of the underlying rationale of the allowances was needed if one was to argue for their continuation and generalization for all women in peacetime. Rathbone pushed for such an interpretative shift, arguing that allowances ought to be understood as a "statutory payment to a woman in respect of her functions as wife and mother," not as soldier's wages for the services he renders for the country (Rathbone 1915, pp. 611-612). She insisted that motherhood and housekeeping ought to be counted as a career in itself entitling women to get paid for their domestic works in the form of family endowment (see Allen 2005, p. 150; Land 1990, p 111; and, Dyhouse 1989, p 102). In Maude Royden's words, "motherhood is a service which entitles a woman to economic independence" (Royden 1917, p. 327).

New feminists did not only motivate their family endowment proposal by the right-based arguments above, but also by proposing economic objections to the notion of family wage. Family wage was an idea associated with the male-breadwinner norm. It was a uniform amount that was supposed to be paid to men conceived as adequate to meet the economic needs of an average fiveperson family, and it made no distinctions between bachelor men, childless couples, and those men with wives and children (Land 1980, p. 63; and, Pedersen 1993, p. 179). It was motivated by the presupposition that men have dependents to feed (not women). Of course; family endowment and family wage were incompatible ideas: if women were paid by the government in recognition of their domestic works, then men had no dependents to feed and there was no justification for the family wage payments to men. In the next section, we will see that such potential effect of family endowments on men's wages led the majority of male-dominated left-wing institutions to stand against the family endowment campaign. That is, both women's movement and Laborism had something at the stake when it came to the family endowment proposal. Not surprisingly, such 
heated debates could attract Ramsey's attention who had just become interested in economic and political questions through his mother's interests in Labor politics and women's rights.

New feminists did not have to be original in criticizing the economic aspects of family wage. Two influential left-wing organizations (which were not male-dominated) had already began to question the rationale of family wage; namely, Fabian Women's Group (FWG) and Women's Cooperative Guild (WCG). In Round About a Pound a Week (1913) and Maternity: Letters from Working Women (1915), published by the FWG and WCG respectively, it was shown that the standard of living of children and mothers were significantly lower than the malebreadwinner of families (Pedersen 1989, p. 94). The FWG also published Wage-Earning Women and Their Dependents (1915), which contained an empirical study showing that more than half of women holding waged works had dependents for whom they were responsible for. This was an important result for it showed that the rationale behind family wage, according to which it is men who have family members economically dependent on them, not women, is flawed (Pedersen 1989, p. 91, and Dyhouse 1989, pp. 100-101). Rathbone cited the empirical findings of this latter publication of FWG and argued against the alleged justification of family wage (Rathbone 1917, p. 62). She continued to criticize the economic aspects of family wage in the next few years. In her widely-read piece The Disinherited Family (1924), she put her economic criticism of family wage in the second chapter of the book. She eventually found it "a sloppy and ill-thought out theory" (Rathbone 1924, p 136), for one, because of its insensitivity to the number of family members economically dependent on the father of family (see Rathbone 1924, pp. 14-38).

In 1917, Rathbone and some other feminists, including Maude Royden and Mary Stocks, established the Family Endowment Committee (FEC) to push for their family endowment demand. 
The government took their proposal seriously and Rathbone's campaign started to gain popularity at the national level (see Pedersen 1989, p. 90). New feminists had found some allied forces within the socialist movement, as well. The women of WCG endorsed the new feminist proposal for family endowments, and they reaffirmed their favorable view on this matter in their 1919 and 1920 congress reports (Pedersen 1993, p 161). Likewise, the FWG held favorable view of the family endowment proposal (Caine 1982, p. 37). British society seemed ready for some fundamental changes in its conception of women's rights. As many as half a million of British women had experienced what it feels to be remunerated by the state in the form of separation allowances during the war (Pedersen 1990, p 991). In 1918 women were partially enfranchised and in the following year they gained access to some unprecedented educational opportunities, thanks to British Sex Disqualification (Removal) Act. To the widespread perception of the society "the family was in crisis" (Allen 2005, p. 138), and to feminists, the time had arrived to push for their demands. Nonetheless, the family endowment proposal soon found strong opponents among the influential political forces of the time (both within and outside of the women's movement), and it turned to an economic reality only after the second world war (Pedersen 1993, p. 139).

\section{THE POLITICS OF MOTHERHOOD}

Feminists did not have a united voice on the family endowment proposal. While new feminists like Rathbone argued for the universal scheme of family endowment, liberal feminists were worried that such endowments would incentivize women to stay at home and would thus promote the separate-sphere ideology against which pre-war suffragists had fought over the years (Pedersen 1993, p. 145). What the post-war liberal feminism wanted was equal pay for equal work, not family endowment. To them, family endowments would not end women's dependence; rather, they would 
“replace private patriarchy with patriarchal state" (Pedersen 1993, p. 149). While in 1918 liberal feminists were running strikes to push for their equal pay demand (see Chassonnery-Zaigouche 2019, p. 129), new feminists gradually gained more and more political power and social presence. In 1919, Rathbone took over the presidency of National Union of Societies for Equal Citizenship (NUSEC), arguably the most influential feminist organization of the time, and from since then she became the principal spokeswoman for new feminism in the 1920s (Pedersen 1993, p. 141).

Although Rathbone valued the ideal of equal pay for equal work, she strongly believed that this demand is to be followed up only after women have achieved economic independence (see Barrett and McIntosh 1980, p. 55; Dyhouse 1989, p. 102; Land 1990, p. 104; Pedersen 1993, pp. 142-144; Kent 1993, p. 119; Misra 1998, p. 382; and, Chassonnery-Zaigouche 2019, pp. 141-142). On the other hand, liberal feminists like Millicent Fawcett thought that equal pay is an achievable objective even though women are not paid for their work at home and are still dependent (Pedersen 1993, p 147). In fact, both feminist camps tried to hit the same target: the male-breadwinner norm, which was operating at its full strength in the post-war Britain comparing to other European countries like France (Lewis 1992). Nonetheless, they took different paths to achieve their goal. New feminism picked the path of gendered division of labor together with state endowments in recognition of the economic value of women's domestic works, whilst liberal feminism insisted on the immediate fight for equal pay. On the whole, the path taken by the new feminism reflected its interest in pursuing the economic demands of working-class families, and the one taken by liberal feminism revealed its prioritization of middle-class demands over others (Pedersen 1993, p. 166; and, Kent 1993, p. 118). We shall see that it was the policy proposals of new feminism, not liberal feminism, to which Ramsey was attracted. 
The family endowment proposal came up in the annual council of NUSEC in 1919. But given the disagreement between liberal feminists and new feminists, it remained a controversial topic for which NUSEC could only take a stance in 1925 when it eventually committed itself to include it in its general program (Pedersen 1993, p. 149). By that time it had attracted too much attention in public debates as Rathbone's Disinherited Family (1924) had reignited the debates over the merits of family endowments. Rathbone (1924) drew on the successful experience of policies similar to family endowment in other countries and proposed a structure for its implementation in Britain. Being hopeless about the new direction of NUSEC led by Rathbone, some liberal feminists resigned from NUSEC on March 1927 and went to organize their voice in some alternative institutions such as Open Door Council, Six Point Group, and the Women's Freedom League (see Kent 1988, pp. 240-243; Dyhouse 1989, p. 103; Pugh 1992, pp. 238-239; and, Allen 2005, p. 151). Unlike new feminists that included welfare and social reform in their program, liberal feminists favored labor market policies, maternity benefits, and child-care policies, remaining worried about the permeation of separate-sphere ideology in women's movement (Land 1990, p. 115; and, Misra 1998, p. 382).

Fabianism was among the influential political forces that got involved in the debate. It was a non-Marxist variation of socialism, interested in gradualism in political change, and associated with the economic orthodoxy of the London School of Economics. As long as the economic shortcomings of family wage was concerned, Fabian women were on board with new feminists. Nonetheless, they were not united in their preference for its replacement. We have seen that those active in the FWG branch of Fabianism held favorable view of family endowment (see section III). Nonetheless, some renown Fabian women like Beatrice Webb were not on board with the majority of FWG members. In 1919, Webb compiled the minority report for the War Cabinet 
Committee on Women in Industry to propose her recommendations on the gendered wage system. In it, she argued that wages must be determined by the occupational rate, and that the rates ought to be fixed by collective bargaining, insensitive to the gender, race, and creed of the worker. Webb insisted that the rejection of family wage and its underlying rationale (i.e. that men have dependents to feed, not women) would pave the way to close, and eventually eliminate, the pay gap between women and men (Gouverneur 2019b, pp 84-85). Thus, Webb was more interested to choose the path of liberal feminism, not new feminism, after overcoming the hurdle of family wage.

Women of the Labor Party and TUC were on board with the liberal attitude of feminists like Fawcett and Webb (Land 1980, p. 69; and, Misra 1998, p. 382). Nonetheless, their view was not shared by the leftist male-dominated organizations. In fact, the Labor Party played a crucial role in the survival of the family wage norm and the unfortunate fate of the family endowment campaign. As mentioned earlier, laborism was worried about the potential adverse effects of family endowments on male workers' wages (Land 1980, pp 65-68). The male-breadwinner norm, against which feminists were united, was an ideal shared by laborism, for it could keep up the bargaining power of male workers in wage negotiations on the ground that men ought to be paid an amount that would be enough for the economic needs of their family, not merely themselves (Pedersen 1989, p. 95). On this, trade unionism was with the Labor Party (see Pedersen 1993, pp. 200-203; and, Stocks 1949, p. 95), and the Labor party's acceptance of the family endowment scheme was contingent on its endorsement by Trade Union Congress (TUC) (Pedersen 1993, p. 220).

The Joint Research and Information Department of the Labor party and the TUC set up the Advisory Committee on Motherhood and Child Endowment in 1921. The committee's report, 
published in 1922, rejected the universal family endowment. The committee also suggested that the demand for endowment could be understood as the demand for improved social services, not cash allowances; a demand that the Labor Party, according to the report, had already considered in its political agenda and policy advocacy. The report was widely accepted. As a result, the Labor Party favored social services over cash allowances for families as they thought this will not bring down wages as allowances would do. Cash allowances were accepted only if the father of family was absent or dead (see Pedersen 1989, pp. 96-98; Pedersen 1993, pp. 162-163; and, Misra 1998, p. 383). Indeed, the 1922 committee report made it clear that laborism and feminism had conflict of interest. Unlike the majority of progressive followers, new feminists prioritized women's rights over men's wages. To them, "family endowment was worthwhile regardless of its effects on wages" (Pedersen 1993, p. 199; emphasis original).

Ramsey knew some of the main figures involved in the controversy very well. Hugh Dalton who was appointed in the Advisory Committee mentioned above (Pederson 1993, p. 163) was a friend of Agnes and remembered her as someone who played a critical positive role in the Cambridge branch of the Labor party. He was a frequent visitor of Ramseys when Frank was at his teens (Misak 2020, p. 10), and Frank continued his relationship with Dalton during his adulthood (see Misak 2020, p. 289)2. Another important figure of the committee was Barbara Drake (Pedersen 1993, 163). Drake had published her Women in the Engineering Trades in 1917, which was recorded in Ramsey's 1920 diary among the books that he read that year (see Misak

\footnotetext{
${ }^{2}$ Dalton joined the Fabian Society in 1907 and then became the president of the Cambridge University Fabian Society (Maccio 2016, p. 712, fn. 26), which was established in 1906 to influence middle-class opinions on politics (Takami 2014). It is difficult to speculate to what extent the 1922 report reflected Dalton's view of the matter; but one can say that whatever his position was in 1922, a few years later, when he was contributing to the Independent Labor Party's campaign for living wage, he held favorable view about family endowments, arguing that endowments would have no negative effects on wages (see Pedersen 1993, p. 199; and, Land 1980, pp. 66-67). In 1926, he called Rathbone's Disinherited Family (1924) as "one of the outstanding contributions to economic literature since the war" (quoted in Pedersen 1993, p. 181).
} 
2020, p. 48). Drake's piece was a report provided in response to an inquiry by a Joint Committee of the Labor Research Department and the FWG. In it, she provided some statistics on women's activity in the wartime market, especially in engineering industries. Perhaps most notably, Drake discussed the family wage controversy and a critical view on family endowments (see Drake 1917, p. 97).

In the end, neither the economic and empirical arguments of feminists nor their right-based arguments seemed convincing to the eyes of family wage proponents. Instead, feminists' resistance against the patriarchal patterns of market payments motivated its staunch proponents to come up with new arguments to support their favorable view of family wage. In 1921, Benjamin S. Rowntree and Frank D. Stuart published The Responsibility of Women Workers for Dependents. In it, they carried out an empirical investigation and claimed that only around $12 \%$ of women workers have dependents. Then, they argued for different minimum wages for men and women on the ground that men have dependents to feed, not women. Their findings were surely at odds with what FWG had reported in 1915. According to Pedersen, Rowntree and Stuart's research was flawed and their conclusions were motivated by their political takes on the question of gender pay gap, not the actual data (see Pedersen 1993, pp. 156-158; and, Pedersen 1989, p. 93). Some economists got interested in the debate, as well. Perhaps most notably, Francis Y. Edgeworth, an Oxford economist, argued that men should be paid more than women because of their family responsibilities. Edgeworth's argument was partly motivated by the empirical "findings" of Rowntree and Stuart's, which he found more reliable than the FWG report (see Edgeworth 1922, p. 449). 
Although British laborism (with the exception of those sections representing women's point of view) stood firm against the opponents of family wage in the immediate years after the war, the Independent Labor Party (ILP) attempted to push laborism to reconsider the merits of family endowments. In its 1926 conference, the ILP launched its campaign for "Socialism in Our Time." The campaign was home to radical intellectuals, activists, and young MPs disaffected by the gradualism of Ramsay MacDonald that had led the first British labor government for nine months in 1924 (Pedersen 1993, p. 189). Redistributive family policies became central to the ILP's program for economic recovery (Pedersen 1993, p. 179). Drawing on under-consumption theories, the ILP members argued that family endowments will increase the purchasing power of workers, that it will create additional demand for goods, and that it will eventually reduce unemployment. They also found the rationale of family endowments in line with the principles of socialism and its conception of justice (Land 1980, p. 66; and, Pedersen 1993, p. 191). The ILP went on to argue for a living wage policy, which was consist of minimum wage together with children allowances. Nonetheless, the Labor party did not share the ILP's enthusiasm for family endowments. Having considered the living wage policy, TUC and the Labor party eventually reaffirmed their position against cash allowances and favored social services to improve family lives (Land 1980, p. 65).

Rathbone believed that the adherence to family wage is not merely driven by economic motives, but also by what she notoriously called "the Turk Complex," or men's tendency to tame women's freedom in family life (see Rathbone 1924, pp. 268-275). Whatever the underlying motives of the proponents of family wage, they achieved to keep the patriarchal patterns of wage system for the next few decades. Perhaps because they had more political power than feminists, or perhaps because they, not new feminists, were seen as the representative of working-class people and their demands. Ramsey's acquaintance with the controversies around the wage system and 
endowments led him to put these issues at the center of his Apostle talks. Nonetheless, there was another important factor that contributed to his view on the politics of motherhood: he was surrounded by Cambridge intellectuals with unorthodox attitudes toward sex and love.

\section{SEX, LOVE, AND FAMILY ENDOWMENT}

We have seen that Agnes successfully passed on her interest in politics to Frank. Nonetheless, she was much less successful to do so when it came to the matters of sex. Frank had fundamental disagreement with her mother over sexual morality (Misak 2020, p. 11). When in 1925 Frank and

Lettice C. Baker were married, they mutually agreed not to limit each other's sexual life. Frank knew that Agnes would not be happy about their decision and so he did his best to keep the matter secret from her mother (see Misak 2020, pp. 205-215). Indeed, Frank and Lettice were not unique in Cambridge of the 1920s. They were surrounded by an older generation of intellectuals who had turned their back to the orthodox notions of sex and love. In 1921, Frank became a member of the Heretics Society, whose debates were centered around religion, art, and philosophy. To the society and its members, being a heretic amounted to subsume the orthodoxy associated with Victorian moral codes (see Duarte 2017, pp. 657-658). Frank was also a frequent attendee of both the Apostles and the Bloomsbury meetings. The former was an all-men secretive intellectual society who were known for their pursuit of brotherly love (Taddeo 1997). Some of them such as Bertrand Russell advocated free love in print (see Misak 2020, p. 249). The Bloomsbury group was mostly home to writers and artists with their famous unorthodox attitude toward sex and love. By and large, Apostles and Bloomsburians were in agreement when it came to the matters of sex. As Desmond Bernal once put it, free love had become "the new religion" in Cambridge (quoted in Misak 2020, p. 148). 
Ramsey’s disinterest in monogamy first appeared in one of his 1920 student essays titled “the Materialist interpretation of History" (ASP.1983.01: 007-02-02). In it, he sympathizes with Edward Jenks's view that "permanent marriage" has been motivated by "the desire of the man to secure for himself exclusively the labour of the woman and her offspring' (Jenks 1900, p. 27; emphasis original). It is true that the post-war Cambridge was home to a significant number of intellectuals with an unorthodox attitude toward sex and love, but that attitude was a local phenomenon, peculiar to Bohemian elitism. The older generation like Agnes surely never shared the enthusiasm of the Apostles, Bloomsburians and alike for free love and homosexuality. Rathbone was bemused once learned about her niece's lesbianism and rejected the view of sex as a source of pleasure (Pedersen 2004, p. 174). Beatrice Webb was concerned with socialist support for free love and Fawcett believed in the merits of traditional family life (Chassonery-Zaigouche 2019, p. 138).

In any case, the then unorthodox practice of love and sex could have important consequences on the social and economic patterns. In "Sex from the Point of View of Society" (1924), Ramsey asked his fellow Apostles to take the consequences of their actions seriously:

"It seems to-day as if the old ideas were collapsing as the religion from which they derive is giving way to vaguer religions, more dissociated from conduct and less definite about morality, and I think we ought to consider whether this movement is a good one, and if so, what, if anything, we should attempt to substitute for the old morality" (Ramsey [1924] 1991, p. 325).

Those "vaguer religions" would decay the "moral feelings about monogamy" and would imply that marriage is not to be regarded "as a long arrangement" anymore (Ramsey [1924] 1991, p. 
327). Then, Ramsey took the collapse of the traditional institution of marriage as something given in his analysis of the early inter-war economic status of women (see also Ramsey [1924] 1991, p. 327; fn. 10). Not a realistic assumption about British society as a whole, but an apt one as long as one's audience was the Apostles.

To Ramsey, abandoning traditional moral codes would have serious consequences on "maintenance of women and children" (Ramsey [1924] 1991, p. 327). If traditional marriage is gradually disappearing for a certain class of society, then it implies that the norms associated with traditional marriage, including the male-breadwinner norm, would become ineffective. Ramsey writes:

"the institution of marriage with its concomitant morality is defended, I suppose, mainly by urging the interests of women and children, and it is regarded as securing to the majority of women maintenance for themselves and their children, in as much as for a respectable woman to give herself to a man without exacting these terms is held to be wicked and so made almost impossible" (Ramsey [1924] 1991, p. 325).

Ramsey then makes a curious comparison between the function of a trade union with the traditional institution of marriage operating under the male-breadwinner norm, which leads him to conceptualize the dynamics of marriage institution in economic terms - an unusual analysis of marriage institution by that time. He says that "the institution [of marriage] resembles in some ways trade union action; except prostitutes are exempted from the union regulations because they supply an inferior article and are not regarded as serious competitors" (Ramsey [1924] 1991, pp 325-326). "Like other forms of trade unionism," he continues, "the marriage system obviously secures better terms for women than they would obtain under free competition, but at the cost of a 
serious amount of unemployment because marriage is made expensive to men" (Ramsey [1924] 1991, p. 326). Ramsey's view ought not to be interpreted as an approving remark on family wage. In fact, Rathbone and other feminists would agree with Ramsey that women's share of the family wage is on whole higher than what they would be paid in a free market, for the gender bias was institutionalized in the wage system. As the following passage indicates, Ramsey was attracted to the new feminists' campaign for family endowment. In "Socialism and Equality of Income" (1923), he writes:

"There is the question whether the cost of a family should be born by the father or the State. On the one hand it seems reasonable that those enjoy the pleasure of having children should bear the cost for it themselves; but on the other hand the principle of making the national income go as far as possible makes reasonable leads towards the maintenance of the children by the State. Evidently the misery of poverty would today be considerably alleviated if incomes were proportioned to the size of the family; and this plan is in fact adopted in poor relief and government pensions and separation allowances" (Ramsey [1923] 1991, p. 318).

In his "Sex from the Point of View of Society" (1924), Ramsey mentions an argument against family endowments according to which "it is unjust that those persons who do not have the pleasure of having children themselves should be forces to contribute to the maintenance of other people's children" (Ramsey [1924] 1991, pp. 327-328). He then responds:

"If now we try to imagine a state in which people are no longer under the influence of present day moral ideas, I think we shall find the chief difficulty to be the maintenance of women and children; and I cannot see any method of avoiding the view that if such a state 
wanted children to be reproduced it would have to undertake their maintenance" (Ramsey [1924] 1991, p. 327).

Note the conditional nature of Ramsey's argument. As mentioned earlier, he takes the collapse of marriage institution as something given in his analysis and this makes it easier for him to see the merits of family endowment. It is also important to note that Ramsey's positive remarks on family endowments were not limited to its economic aspects. He also acknowledges an important sideproduct of this policy; that is, the economic freedom of women - what new feminists highly valued:

"[S]uch a state [that implements the family endowment policy], it seems to me, might well be more attractive to women than the present one; it would give them much more independence in their relations with men. By marriage a woman loses much of her independence; among the lower classes, anyhow; she looses the advantage of having her own money, a loss which is supposed sufficient to make many married women go out to work in order to obtain pocket money of their own. If women were paid by the state for having children, and for housekeeping and so on by the man they lived with they would be in much more independent position" (Ramsey [1924] 1991, p. 328)

One can imagine such statements to come out of Rathbone's pen with an important difference that Ramsey's positive view on family endowments was, at least in part, motivated by his observation of the Bohemian attitude to sexual life. Nonetheless, there was another important incentive constitutive to Ramsey's stance on the politics of motherhood: his interest in Freud.

\section{RAMSEY'S MATERNALISM}


In 1924, Ramsey decided to spend six months in Vienna to be psychoanalyzed by Theodor Reik (the writer of the first $\mathrm{PhD}$ dissertation on psychoanalysis) as he was anxious in sexual life (see Misak 2020, 150-170). After his return to Cambridge, he followed up his interest in Freud by engaging himself with a Cambridge group named "Psych An Society." Ramsey was among its formative members, along with the biographer Lytton Strachey and the mathematical statistician Harold Jeffreys. All of the group members had been psychoanalyzed themselves. Their first meeting was held on March $2^{\text {nd }}, 1925$ and the group petered out after a year (Misak 2020, pp. 220222; and, Forrester and Cameron 2017, chap. 6).

Ramsey's interest in psychoanalysis manifested itself in his 1924 and 1925 Apostle talks. In “An Imaginary Conversation with John Stuart Mill," read on January $26^{\text {th }}$, 1924, he imagined a dialogue centered around Mill's mental break-down at the early age of twenty, and how Mill eventually emancipated himself from the tight grip of depression. This was before Ramsey was analyzed and it was when his mood was still down. In this talk, Ramsey supports Freudian psychoanalysis as an advanced psychological theory that reveals how simplistic Mill's utilitarianism is.

Ramsey delivered his "Civilization and Happiness" (1925) on November 1925, when he was still attending the Sunday meetings of Psych An Society. In this last Apostle talk of his, Ramsey conceived of civilization as a "burden." He thought that this burden "has lately been and is still enormously increasing in the case of the female sex," an observation that leads him "to a general consideration of feminism" (Ramsey [1925] 1991, p. 322). Adopting a language akin to Freud's, he stated that the prospering of British economy had been the consequence of the unconscious employment of sublimation and repression of British men's sexual desires. Analyzing the effects of this process on the society, he held that Englishmen's relations with men have been 
"more important to them than their relations with women" (Ramsey [1925] 1991, p. 322). "Colleges' feasts and city dinners," he continued, "are typically English homosexual functions" (Ramsey [1925] 1991, p. 323) - such was a young Cambridge man's worries talking in front of the Apostles. The unconventional attitudes of Englishmen, Ramsey thought, have incentivized Englishwomen to find a solution for this problematic aspect of their everyday life. Their solution, however, was not a good one to Ramsey:

"Women have long wanted a better position, and are seeking education and emancipation generally. They are trying to imitate or rival men in vocations for which they are on the average less fitted by nature, and though this rivalry and education becoming less feminine and less capable of feminine happiness. The point seems to me to be that they are not trying to raise the position of the female sex, by making themselves more important to men in a feminine way, so that men's lives revolved round women. This they could hardly manage; so that they are naturally trying to better themselves by the alternative method of becoming as far as possible men instead of women" (Ramsey [1925] 1991, p. 323).

Ramsey warns women not to "imitate" men and not to masculinize their very "nature." His commitment to the separate-sphere ideology is evident in the passage above and it seems to be driven by the Freudian view that was insisting on the biological differences between men and women. According to Kent (1990), it was the very implication of Freud's "Some Psychological Consequences of the Anatomical Distinction Between the Sexes" ([1925] 1927) that women's lifelong dissatisfaction caused by penis envy could be overcome by child-rearing and motherhood. It would not be a far speculation to say that Freud's 1925 article was the matter at debate in the 1925 
Psych An Society meetings that saw Ramsey as an active member ${ }^{3}$. In any case, Freud's 1925 article aside, Ramsey was certainly well-aware of Freud's theory of sexual development and its implication for what constitutes gender through his acquaintance with Freud's Three Essays on the Theory of Sexuality (1905) $)^{4}$. Then, two options seem to be open for interpretation of Ramsey's remarks above: first, Ramsey ought to be understood as a representative of an antifeminist whose account of gendered division of labor was inspired by his interest in psychoanalysis; and, second, Ramsey's positive view of the separate sphere ideology was driven by his joint interest in new feminism and psychoanalysis. I shall argue for the latter interpretation. As Kent (1988, 1990, and 1993) suggests, new feminism and psychoanalysis had tight connection in the aftermath of the Great War. Although both interpretations are underdetermined by the piece of textual evidence above, Ramsey's positive remarks on family endowment and women's economic independence in his other Apostle talks (see sections IV and V) add more credibility to the latter interpretation.

Although prewar feminists understood masculinity and femininity as cultural products and not biologically determined concepts (Kent 1988, p. 233; and, Allen 2005, p. 188), new feminists embraced "the primacy of sexual difference in determining the relations between men and women" (Kent 1990, p. 71). To Rathbone, there was "scarcely a department of human activity in which the physiological differences between men and women and the ensuing differences in their activities have not some effect, though in many departments it may be only slight, upon the outlook of the

\footnotetext{
${ }^{3}$ Although James Strachey's translation of Freud's 1925 article into English appeared in the International Journal of Psycho-Analysis in 1927, Ramsey could have read the original version of the article in German right after its publication in 1925, for he had shown his advanced skills in German language when translating Wittgenstein's Tractatus (1922) into English. After all, Paul's remarks support this conjecture. After quoting some passages of his brother's 'Civilization and Happiness' (1925), Paul writes that "it seems likely that Frank had read the then recent paper by Freud on the subject of women" (Paul 2012, 220). In a footnote, she clarifies what paper of Freud she has in mind: "Some Psychological Consequences of the Anatomical Distinction between the Sexes'; first read at the Homberg International Psychoanalytical Congress, 3 September 1925" (Paul 2012, 289, fn. 7).

${ }^{4}$ Ramsey's careful and lengthy notes on Freud (1905) can be found in Ramsey's notes titled 'Psychoanalysis' (ASP.1983.01: 003-01-01).
} 
two sexes" (1927, p. 3; see also Rathbone 1917, p. 59, and Pedersen 1989, p. 91). The changing conception of what constitutes gender (from a cultural account to a biological one) that manifested itself in the post-war new feminist writings was driven by the then psychoanalytic and sexological literature (Kent 1990, p. 67; and, 1993, p. 125). In November 1925, about the time Ramsey delivered his last Apostle talk, Ray Strachey, a liberal feminist, observed that "the latest craze, apparently, is to discuss the 'essential' differences of men and women, and to call in all the new psycho-analytical vocabulary for the purpose of saying the same old things [on the separate-sphere ideology] in a new form [of new feminism]" (quoted in Kent 1993, p. 134). In Freudian psychoanalysis, "happiness and health for women... depended upon motherhood" (Kent 1990, p. 73). Likewise, Ramsey held that women had "fundamental instincts for marriage and motherhood" (Ramsey [1925] 1991, p. 323). In Jeffreys' words, “the ideal of sexually fulfilling motherhood... had by the 1920s been absorbed into the 'new feminism' of Eleanor Rathbone and other women in the National Union for Equal Citizenship" (1997, p. 146). It was this new feminist biologicallybased account of gender equality that made them look like pre-war anti-feminists to the eyes of liberal feminists (Kent 1993, pp. 117-121).

In her 1925 NUSEC presidential address, only about eight months before the time that Ramsey expressed his worries about those women attempting to masculinize their "nature," Rathbone had put forward striking similar remarks to Ramsey's. The time had arrived, she thought, for the emergence of "the new feminism" with its new account of gender equality:

"At last we can stop looking at our problems through men's eyes and discussing them in men's phraseology. We can demand what we want for women, not because it is what men 
have got, but because it is what women need to fulfill the potentialities of their own natures and to adjust themselves to the circumstances of their own lives" (Rathbone 1925, p. 52).

Thus, it seems that Ramsey was consciously following up his interests in psychoanalysis and new feminism in tandem. He had seen the conceptual commonalities between Freud's theory of sexual development and the new feminist account of gender equality that underpinned their positive view on the gendered division of labor. Post-war new feminism and Freudian psychoanalysis were each other's ally, and Ramsey's maternalism was the resultant of his joint interest in these two influential movements. Taking account for such contextual matters may help us to interpret Ramsey's controversial remarks on feminism in an apt way. In his 1925 Apostle talk, he put forward explicit critical remarks on what he takes to be "feminism." He writes:

"Not merely is feminism bad for the race but it is unfortunate for the women also, who are forced away from the kind of life which they are fitted by nature to enjoy, to one which can only give them secondary satisfaction" (Ramsey [1925] 1991, p. 324).

The passage above is not as straightforward as it seems. There are two subtle points that need to be explained: Ramsey's usage of the term "feminism" and his eugenic criticism of it. I shall address these two points in turn.

According to Ramsey, the feminism that he has in mind forces women away from doing what they are fitted to by nature. It is supposedly motherhood and domestic works that fit women's nature, not working outside home. Thus, the feminism that Ramsey refers to must be the one that encourages women to work outside, not the one that was advocating maternalism together with family endowments. That is, the term "feminism" above ought to be understood as "liberal 
feminism," not the "new feminism" of Rathbone. One should note that "new feminism" and "liberal feminism" were not common words in the political discourse by the time Ramsey delivered his Apostle talks. Rathbone introduced her position as "new feminism" in her 1925 NUSEC presidential address. The difference between the two branches of feminism became more explicit and widely identifiable only after the institutional split within British women's movement on March 1927 (see section III); that is, when liberal feminists resigned from NUSEC that was being led by Rathbone "to oppose what they considered a dangerous emphasis on gender difference at the expense of equality" (Allen 2005, p. 141). Ramsey was not alone in using "feminism" to refer to the position held by liberal feminists. Freud used the term in the same way when wrote on "the denials of feminists, who are anxious to force us to regard the two sexes as completely equal in position and worth" ([1925] 1927, p. 142). In 1920, Karl Abraham described feminists as those who mistakenly "consider that the sex of a person has nothing to do with his or her capacities, especially in the mental field" (quoted in Kent 1990, p. 74). Likewise, Ernest Jones, Ramsey's fellow member of Psych and Society, used "feminism" to refer to those denying the "differences between the sexes" (Forrester 2017, p. 179, fn. 228). Thus, it seems that what was later known as new feminism was excluded from Ramsey's harsh criticism of "feminism" mentioned above, for they themselves drew upon the works of such psychoanalysts to justify their maternalism, which they saw complementary to their family endowment campaign. Paul (2012) is right in saying that Ramsey's talk was "an attack on feminism" (p. 219), but in retrospect it would be more accurate to say that it was an attack on liberal feminism.

We have seen that Ramsey held that (liberal) feminism is bad "for the race." Right after his negative remarks on those women trying to imitate men (quoted above), he reiterates his eugenic concern about the feminist demands with liberal tendency: 
"This process must I think have the unfortunate consequence of weakening the race. On the whole, the more intelligent women will be educated, and of educated women a relatively small proportion marry, and those who do tend to have fewer children than others" (Ramsey [1925] 1991, p. 323).

It was not only the demands of liberal feminists that could attract eugenic considerations. The new feminist campaign for family endowment dealt with similar types of criticism, as well. Although their maternalism seemed fine in view of eugenicists, their family endowment policy could have increased the lower-class population and was a matter of concern for whoever was worried about the effects of such policy on the quantity and quality of population. But, Ramsey thought, there is a solution out of the negative eugenic effects of family endowments. In "Socialism and Equality of Income" (1923), after putting some positive remarks on "the maintenance of the children by the State," he writes:

"The chief objection to it [family endowment] to-day is that it would probably tend to increase the population; but whether that objection will maintain its force when people know about birth control and are educated enough to practice it seems to me very doubtful" (Ramsey [1924] 1991, pp. 318-319).

Ramsey put forward similar remarks in "Sex from the Point of View of Society" (1924). In it, he discusses a couple of objections to family endowments, the first of which is: "with the birth rate as high as it is it would be wrong to offer financial inducements which might raise it still higher." Nonetheless, Ramsey reiterates that there is a remedy for such negative effects of family endowments: spreading the knowledge of contraception methods (Ramsey [1924] 1991, p. 327). 
New feminists were fully aware that an important obstacle against their campaign for endowment of motherhood was the eugenic objections to their economic plan. Rathbone had addressed the matter in chapter six of her book where she discussed and undermined "The Fear of Over-population or Mal-population" regarding family endowments (1924, pp. 232-247). She held that eugenic considerations ought to be at play once working out the details of the preferred form of family endowments (see Rathbone 1924, p. 232). One solution was the one that Ramsey had in mind; that is, trying to convince the government to provide birth control information and contraceptive methods to married women, which could be seen as a complementary plan to the family endowment campaign. In fact, by 1925, Rathbone had "two new reforms" in mind that "she wished to be included in the NUSEC immediate programme: birth control and family allowances" (Smith 1990, p. 56). By 1925, the new feminists succeeded to include the birth control advocacy in the NUSEC agenda. Shortly after, they lobbied the Ministry of Health with the help of the women of the Labor Party, which resulted in allowing the provision of birth control information at public clinics. Thus, on advocating birth control information and the accessibility of contraceptive methods, Ramsey followed up new feminists, and the women of the Labor Party, not the men of the Labor Party that stood against this policy (see Smith 1990, pp. 56-57; Kent 1993, p. 131-132; Hoggart 2000, p. 105; and, Allen 2005, pp 164-165).

\footnotetext{
${ }^{5}$ In addition to the birth control advocacy, Ramsey gave two more hints at how the negative eugenic effects of family endowments could be avoided. First, he held that "the danger that women would have too many children to get the money for them could, I think, be averted by reducing enormously the payment for any children after the first few" (Ramsey [1924] 1991, p. 328). On this, Ramsey's view was essentially the same as what Rathbone had called the "downward graded" system for family endowments (see Rathbone 1924, pp. 289-290). Second, Ramsey thought that family endowments, unlike family wage, ought not to be paid in a universal flat rate, "for if we were to pay a flat rate, so much for the first child, so much for the second child, and so on we could not afford enough to attract the best kind of woman" (Ramsey [1924] 1991, p. 328; emphasis added). Instead of a flat rate, Ramsey argued, there ought to be some opportunity cost considerations to determine the optimum rate for each woman: "the amount a woman is to be paid to bear and rear a child must, it would seem, depend on her social standing or perhaps on the amount she could have earned by adopting some profession other than that of motherhood" (Ramsey [1924] 1991, pp. 327-328).
} 
The eugenic aspect of family endowments drew the attention of economists, as well. Edgeworth considered women responsible for both family life and the future of human race (Chassonery-Zaigouche and Cot, forthcoming). He held that "the increase of population might be welcomed if it consisted of the higher types," however, he thought, family endowments would not result in "the improvement of the race" for it increases the quantity of "the least desirable classes" (1922, p. 454; see also 1924, p. 448).

Cambridge Welfare economics tradition had also a history of eugenic considerations as part of its economic analysis of welfare policies. Marshall's maternalism had tight bond with his eugenic view. Like Edgeworth, Marshall had found women responsible for the improvement of race and the efficiency of the future generations of market labor-force. Once observing that "the wages of women are... rising fast relatively to those of men's", Marshall became worried that this may prompt women "to neglect their duty of building up a true home, and of investing their efforts in the personal capital of their children's character and abilities" (Marshall [1920] 2013, p. 570; emphasis added). Marshall's maternalism and eugenic concerns led him to argue for a genderspecific minimum wage with a family wage for men and a subsistence wage for women (see Bankovsky 2019, pp. 261-262). In addition, he held favorable view of the Factory Acts which were to restrict women's access to waged works (see Pujol 1992, chap. 8, and Gouverneur 2019a). He also objected to the policies like Old Poor Law and New Poor Law on the ground that they increase the birth rate within the working-class (Bankovsky 2019). Like Marshall, Pigou was a proseparate-sphere ideology. "There can be no doubt that," Pigou thought, "the work done by women in factories" will bring about "grave injury to the health of their children" (Pigou 1920, pp. 162163). Hence, his advocacy for the government intervention to reduce the working hours of married women (Aslanbeigui 1997, p. 309). Pigou's solution for avoiding what he took as the negative 
eugenic consequences of endowments was sterilization of the worst group of working-class people (Pigou 1907, p. 369).

Ramsey never advocated a negative eugenic measure like fertilization with Pigou. As mentioned above, he thought providing birth control information and the accessibility of contraceptive methods would be enough as a complementary policy to family endowments. Nonetheless, Ramsey's style of engagement with the family endowment controversy was akin to what could be found in the Cambridge welfare tradition. He was sensitive to the eugenic aspects of family endowments and he was a pro-maternalist. His policy debates, however, were not merely driven by what he had learned as a Cambridge economist. He had wide intellectual interests in the politics of motherhood and Freudian psychoanalysis, and his position on the role of women in economy ought to be understood within the political and intellectual context of the time that went beyond the Cambridge economics tradition.

Acknowledgement: I would like to express my deep appreciation to Cheryl Misak and Kevin Hoover. This work would not have been possible without their invaluable advice and guidance. I am also immensely grateful to Pedro Duarte, Joseph Berkovitz, Mark Solovey, Nathalie Sigot, and the anonymous referees for their helpful comments on the earlier draft of this paper. I also thank participants to the Center for the History of Political Economy lunch seminar at Duke University on November 2020.

\section{REFERENCES:}

Allen, Ann. 2005. Feminism and Motherhood in Western Europe, 1890-1970: The Maternal Dilemma. Springer. 
Aslanbeigui, Nahid. 1997. Rethinking Pigou's Misogyny. Eastern Economic Journal 23 (3): 301316.

Barrett, Michelle., \& McIntosh, Mary. 1980. The 'family wage': some problems for socialists and feminists. Capital \& Class, 4 (2), 51-72.

Caine, Barbara. 1982. Beatrice Webb and the "Woman Question." History Workshop (14): 23 43.

Chassonnery-Zaigouche, Cleo., and Cot, Annie L. Forthcoming. Sentiment and Prejudice: Francis Ysidro Edgeworth on Women's Wages.

Chassonnery-Zaigouche, Cleo. 2019. Is Equal Pay Worth It? Beatrice Potter Webb's, Millicent Garrett Fawcett's and Eleanor Rathbone's Changing Arguments. In Kirsten Madden \& Robert W. Dimand, eds., Routledge Handbook of the History of Women's Economic Thought. Routledge, pp. $129-149$

Duarte, Pedro G. 2009. Frank P. Ramsey: A Cambridge Economist. History of political economy, 41(3), 445-470.

Duarte, Pedro G. 2017. Frank P. Ramsey (1903-1930). In Robert A. Cord, ed., The Palgrave Companion to Cambridge Economics. Palgrave Macmillan, pp. 649-671.

Dyhouse, Carol. 1989. Feminism and the Family in England 1880-1939. Basil Blackwell.

Edgeworth, Francis Y. 1922. Equal pay to men and women for equal work. The Economic Journal 32 (128): 431-457. 
Forrester, John. and Laura Cameron. 2017. Freud in Cambridge. Cambridge University Press.

Forrester, John. 2004. Freud in Cambridge. Critical Quarterly 46 (2): 1-26.

Freud, Sigmund. [1905] 1949. Three Essays on the Theory of Sexuality. London: Imago Publishing Go.

[1925] 1927. Some Psychological Consequences of the Anatomical Distinction Between the Sexes". International Journal of Psycho-Analysis 8: 133-142.

Gaspard, Marion. 2003. Ramsey's theory of National Saving: a mathematician in Cambridge. Journal of the History of Economic Thought, 25(4), 413-435.

2005. Individual Behaviors and Collective Welfare: Ramsey’s "Microfoundations" of "Macro-equilibrium." Paper presented at the IRES (Institut de recherches économiques et sociales) conference, Université Catholique de Louvain.

Gouverneur, Virginie. 2019a. Alfred Marshall on the housewives' unpaid work: at the boundaries of Economics. Communication at the 2019 Annual Conference of the History of Economics Society, Columbia University (New York), June 20-23.

2019b. Harriet Taylor Mill, Mary Paley Marshall and Beatrice Potter Webb: Women Economists and Economists' Wives. In Kirsten Madden \& Robert W. Dimand, eds., Routledge Handbook of the History of Women's Economic Thought. Routledge, pp. 73-89.

Gregory, Adrian. 2008. The last great war: British society and the first world war. Cambridge University Press. 
Hoggart, Lesley. 2000. Socialist feminism, reproductive rights and political action. Capital \& Class, 24(1): 95-125.

Jeffreys, Sheila. 1997. The spinster and her enemies: Feminism and sexuality, 1880-1930. Spinifex Press.

Jenks, Edward. 1900. A History of Politics. The Macmillan Company.

Kent, Susan. 1988. The politics of sexual difference: World War I and the demise of British feminism. The Journal of British Studies, 27(3), 232-253.

1990. Gender Reconstruction After the First World War. In Harold Smith, ed., British feminism in the twentieth century. University of Massachusetts Press, pp. 66-83.

1993. Making Peace: the reconstruction of gender in interwar Britain. Princeton University Press.

Land, Hilary. 1980. The Family Wage. Feminist Review, 6 (1), 55-77.

1990. Eleanor Rathbone and the Economy of the Family. In Harold Smith, ed., British feminism in the twentieth century. University of Massachusetts Press, pp. 104-123.

Lewis, Jane. 1992. Gender and the development of welfare regimes. Journal of European social policy, 2(3), 159-173.

Macciò, Donnini. 2016. “The Apostles' justice: Cambridge reflections on economic inequality from Moore's Principia Ethica to Keynes's General Theory (1903-36)." Cambridge journal of economics, 40 (3), 701-726. 
Marshall, Alfred. [1920] 2013. Principles of Economics, $8^{\text {th }}$ edition. Palgrave.

Misra, Joya. 1998. "Mothers or workers? The Value of Women's labor: Women and the Emergence of Family Allowance Policy.” Gender \& Society, 12 (4), 376-399.

Misak, Cheryl. 2020. Frank P. Ramsey: A Sheer Excess of Powers. Oxford University Press.

Paul, Margaret. 2012. Frank Ramsey (1903-1930): A Sister's Memoir. Smith-Gordon.

Pedersen, Susan. 1989. The failure of feminism in the making of the British welfare state. Radical History Review, 1989 (43), 86-110.

(1990). Gender, welfare, and citizenship in Britain during the Great War. The American Historical Review, 95(4), 983-1006.

(1993). Family, dependence, and the origins of the welfare state: Britain and France, 1914-1945. Cambridge University Press.

(2004). Eleanor Rathbone and the Politics of Conscience. Yale University Press.

Pigou, Arthur C. 1920. The Economics of Welfare. Macmillan

Pugh, Martin. 1992. Women and the Women's Movement in Britain since 1914. Macmillan International Higher Education.

Ramsey, Frank P. 1923. Socialism and Equality of Income. In Frank P. Ramsey, Notes on Philosophy, Probability and Mathematics, edited by Maria C. Galavotti. Naples, Italy: BibliopolisEdizioni di filosofia e scienze, 1991, pp. 313-19. 
1924. An Imaginary Conversation with John Stuart Mill. In Frank P. Ramsey, Notes on Philosophy, Probability and Mathematics, edited by Maria C. Galavotti. Naples, Italy: Bibliopolis-Edizioni di filosofia e scienze, 1991, pp. 302-312.

1924. Sex from the Point of View of Society. In Frank P. Ramsey, Notes on Philosophy, Probability and Mathematics, edited by Maria C. Galavotti. Naples, Italy: BibliopolisEdizioni di filosofia e scienze, 1991, pp. 325-329.

1925. Civilization and Happiness. In Frank P. Ramsey, Notes on Philosophy, Probability and Mathematics, edited by Maria C. Galavotti. Naples, Italy: Bibliopolis-Edizioni di filosofia e scienze, 1991, pp. 320-324.

1927. A Contribution to the Theory of Taxation. The Economic Journal, 37 (145):

$47-61$

1928. A mathematical theory of saving. The economic journal, 38 (152): 543-559.

1920-1930. Frank Plumpton Ramsey Papers, 1920-1930, Archives of Scientific Philosophy, Special Collections Department, University of Pittsburgh. Cited as “ASP.1983.01" by box and folder number.

Rathbone, Eleanor. “Separation Allowances: I,” Common Cause, 7, no. 359 (February 25, 1915): $611-12$

1917. "The remuneration of women's services." The Economic Journal, 27 (105), $55-68$ 
1924. Disinherited Family: A Plea for the Endowment of the Family. London:

Edward Arnold and Company.

1925. "The Old and the New Feminism." The Woman's Leader (March 13): 51-52.

1927. "What is Equality?” The Woman's Leader (February 11): 3.

Royden, Maude. 1917. "State Endowment of Motherhood," Common Cause, 9: 445 (19 Oct. 1917): 327.

Smith, Harold L. 1990. "British Feminism in the 1920s." In Harold Smith, ed., British feminism in the twentieth century. University of Massachusetts Press, pp. 47-65.

Stocks, Mary D. 1949. Eleanor Rathbone: A Biography. London, Gollancz.

Taddeo, Jullie. A. 1997. "Plato's Apostles: Edwardian Cambridge and the 'New Style of Love"”. Journal of the History of Sexuality, 8(2), 196-228.

Takami, Norikazu. 2014. The Sanguine Science: The Historical Contexts of AC Pigou's Welfare Economics. History of Political Economy, 46 (3), 357-386. 